\title{
水溶性亜鉛フタロシアニン（ $\mathrm{ZnSPc})$ を利用した光化学寮法の
}

\section{研究 一スルホ基数の相違と光化学効果の検討一}

竹野哲、蒲池利章、大倉一郎、廣田順二

西坂剖

東京工業大学生物工学科

東京農工大保健管理センター

\begin{abstract}
Zinc-sulfo-phthalocyanine mixture (ZnSPc:IIgroup) was compared with zinc-tetra-sulfo-phthalocyanine (ZnTSPC:Igroup) in their ability to sensitize cells to red light. Both groups were prepared in order to obtain the required concentration $\left(4.0 \times 10^{-5} \mathrm{M}-4.0 \times 10^{-8} \mathrm{M}\right)$, and incubated with Hela cells for 30 min before laser-irradiation. Cells were damaged strongly by IIgroup even if the concentration and the irradiation energy was lower $\left(4.0 \times 10^{-7} \mathrm{M}, 1 \mathrm{~J} / \mathrm{cm}^{2}\right)$. Moreover, a large difference between cellular morphological changes of two groups was recognized.
\end{abstract}

はじめに

水溶性亚鉛フタロシアニン（ZnSPc, Fig.1）は、 HpD などの従来の感光色素と比べ、Fig.2で見ら れるように組较透過性の良い長波畏側の光を良く 吸収し、また腫窎への集積性が良いことなどから、 光化学寮法においてはその有用性が注目されてい る。今回は Fig.1 のようにスルホ基の数が異なる ZnSPc を合成し、Fig.1-(4)の楧造式をもつものを I 群とし、Pig.1-(1)〜 (4)の混合物をII群として各 群における殺細胞効果の比較検討を行った。

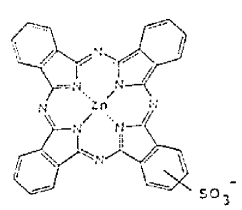

(i) $2 n: i s P_{c}$

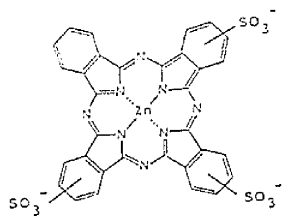

(3) ZnTrispc

I群：(4)のみ ( $\mathrm{ZnTSPC})$

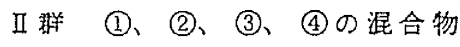

Fig. 1 Z n S P C の粠造

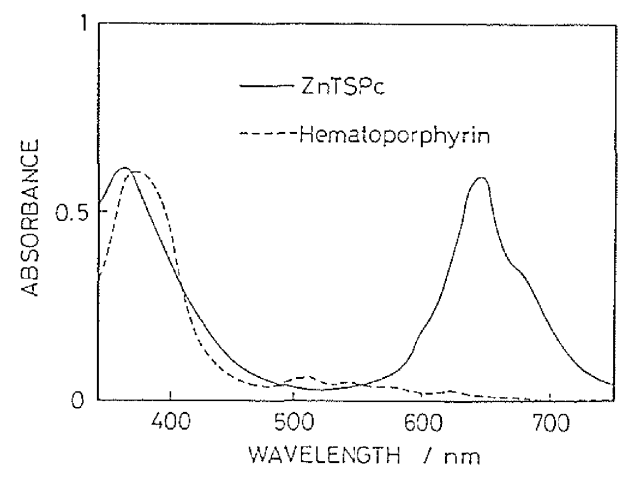

Fig. 2 ZnTSPc と HpD の吸収スペクトル

実験方法および結果

本研究では、対数增殖期にある HeLa 細胞用い た。レーザー光照射は、Arレーザー励起 DCM 色素レーサーを用い、その照射条件は Pig. 3 に示 した。 


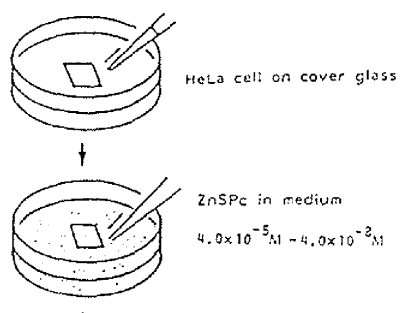

（2）PDT による細胞の形態变化

電子䫓徽鏡観察用のサンプルには、カバーグラ ス上に培皦した HeLa 細胞を用い、光照射 4 時間 後より固定、脱水などの処理を行った。

結果はFig.4 に示す。b はI群によるPDT 後 の形態变化である。この变化は時間の経過と共に
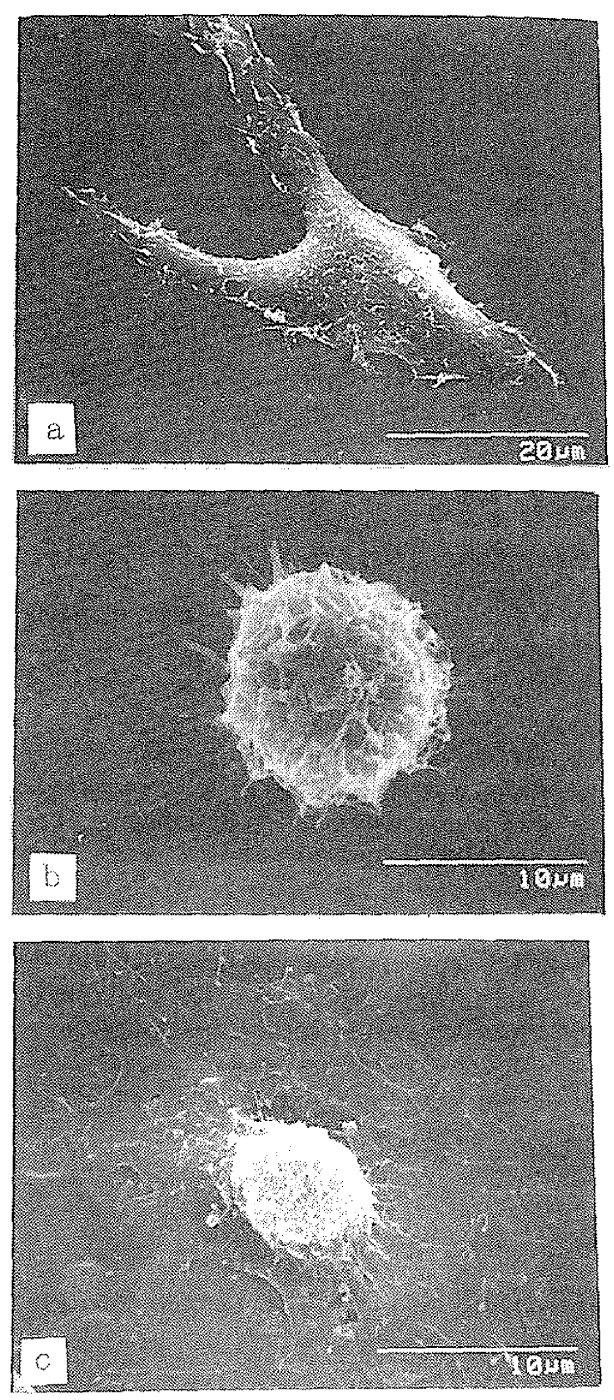

Fig.4 P D T後の形熊変化
a. CONTROL
b. I 群、照射 4 時間後
c. II 群、照射直後 
進行し、光照射後 4 時間経過すると、四のように 核を中心とする球形変化をした。cは五群による 照射直後の形態变化である。a や b と比較すると、 細胞は輪郭を保ったまま核が贫出している。この 核の平坦化は、細胞液の流出によるものと思われ る。そしてこの細胞は時間が経温しても、これ以 上の変化はみられなかった。

\section{考察}

これまでの我々の水溶性亜鉛フタロシアニンに 関する研究11，21，31，4，51，6)では、すべてI群、 すなわちスルホ基の 4 つ付いた ZnTSPc を报って きた。ところか、親水性が强いと細胞膜の透過性 が硠くないといわれており、B.Paquette らはスル 木基が2つ付いたフタロシアニンを用いれは、親 水性の部分と踈水性の部分の両方を合わせ持って いるので、細胞内に取り込まれる効率が上がるの ではないかというモテルを提䞎しだ!。しかし、 混合物の中からスルホ基が $2 つ$ 付いたものだけを 単離し、同定することは非常に困難である。その

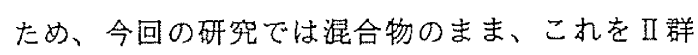
としてI群との比敷を行ったが、それでも非常に 儤れた感光色素であることが判明した。

\section{まとめ}

1. I 群とII 群との比較では、II群の方がより低い 温度およびより低いエネルギーにおいても僈れ た殺細施効果を示した。

2. 細胞の致死過程を形態学的に見ると、I群では PDT 後徐々に球形に変化して死に至るのに対し て、II群ではPDT の最中、あるいは直後に死 城し、細胞液が流出する。

3. II群の場合、きわめて細胞に取り込まれやすく、 PDT によって細胞膜がおおきなダメージを受 けるものと推測される。
文献

1）西坂 剛他：光化学治療における感光色素、 Phthalocyaninek関する基礎的研究（I）、日本 レーザー医学会誌 7:138-140,1987

2）西坂 㓮他：光化学察法における水溶性重 鉛フタロシアニンに関する基礎的研究、日本レー ザー医学会誌 8:69-70,1987

3）西坂 用他：水溶性亜鉛フタロシアニンを 利用した光化学寮法の研究 (I) ZnTSPc の合成 と精製、日本レーザー医学会誌 9:363-366, 1989 4) 西坂 㓮他： 水溶性亜鉛フタロシアニンを 利用した光化学寮法の研究 (II) ZnTSPc の光学 的特性、日本レーザー医学会誌 $9: 367-369,1989$ 5）西坂 夙他：水溶性亜鉆フタロシアニンを 利用した光化学㙩法の研究 ZnTSPc の培細胞へ の取り込みと排出、日本レーザー医学会誌 10 : 253-255, 1989

6）西坂 剛他：水溶性亜鉛フタロシアニンを 利用した光化学寮法の研究 一官能基の相違と光 化学効果の橹討一、日本レーザー医学会読 10 : 257-259, 1989

7) B. Paquette, H.Ali, R. Langlois and J.E.van Lier: Biological Activities of Phthalocyanines-VII, Cellular Distribution in V-79 Chinese Hamster Cells and Phototoxicity of Selectively Sulfonated Aluminum Phthalocyanines, Photochem. photobiol. 47:215-220,1988 